\title{
Prey Selection by Bengal Tiger PANthera tigRIS tigris (MAMmalia: Carnivora: Felidae) of Chitwan National Park, Nepal
}

\author{
Saneer Lamichhane ${ }^{1}$ \& Bibhuti Ranjan Jha ${ }^{2}$ \\ ${ }^{1} \mathrm{MSc}$ in Environmental Science, Kathmandu University, Dhulikel, Nepal \\ Environmental Safeguard Consultant, District Technical Office, Udayapur, Strengthening the National Rural Transport \\ Program (SNRTP), Department of Local Infrastructure Development and Agricultural Roads (DoLIDAR) \\ Ministry of Federal Affairs and Local Development (MoFALD), Nepal \\ ${ }^{2}$ Associate Professor, Department of Environmental Science and Engineering, Kathmandu University, \\ Dhulikel, Nepal \\ ${ }^{1}$ saneerlamichhane@gmail.com (corresponding author), ${ }^{2}$ bibhuti@ku.edu.np
}

ISSN 0974-7907 (Online) ISSN $0974-7893$ (Print)

\begin{abstract}
Prey selection by tiger in Chitwan National Park, Nepal was studied from 77 tiger scats that contained the remains of principal prey species. The scats were collected from January to March 2010. Government reports on herbivore population in Chitwan provided the base data on density of principal prey species. In order to understand prey selectivity, the observed proportion of prey species in the scats were compared with the expected proportion derived from density estimates. The observed scat frequency of Sambar, Hog Deer and Wild Boar was found to be greater than the estimated frequency, and the reverse was true for Chital and Muntjac. The average weight of the principal prey species killed was $84 \mathrm{~kg}$. According to our results, Chital and Sambar constituted the bulk (82.07\%), and Hog Deer, Wild Boar, and Muntjac constituted $17.93 \%$ of the tiger diet. Sambar contributed the largest bulk (43.75\%) of prey composition, but Chital constituted the relatively most killed $(50.36 \%)$ prey species. The present study makes a contribution to an understanding of the status of prey composition in tiger scat in Chitwan during the year 2010. The study also highlights that both large and medium sized prey are important for the conservation of tiger in Chitwan National Park.
\end{abstract}

Keywords: Panthera tigris, principal prey species, prey selection, scat analysis, tiger.

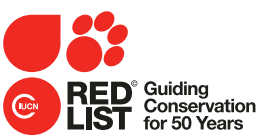

DOI: http://dx.doi.org/10.11609/jott.2424.7.14.8081-8088

Editor: L.A.K. Singh, Bhubaneswar, Odisha, India.

Date of publication: 26 November 2015 (online \& print)

Manuscript details: Ms \# 03580 | Received 10 April 2013 | Final received 30 October 2015 | Finally accepted 05 November 2015

Citation: Lamichhane, S. \& B.R. Jha (2015). Prey selection by Bengal Tiger Panthera tigris tigris (Mammalia: Carnivora: Felidae) of Chitwan National Park, Nepal . Journal of Threatened Taxa 7(14): 8081-8088; http://dx.doi.org/10.11609/jott.2424.7.14.8081-8088

Copyright: (C) Lamichhane \& Jha 2015. Creative Commons Attribution 4.0 International License. JoTT allows unrestricted use of this article in any medium, reproduction and distribution by providing adequate credit to the authors and the source of publication.

Funding: Kathmandu University, National Trust for Nature Conservation.

Conflict of Interest: The authors declare no competing interests.

Author Details: Saneer Lamichhane is working as an Environmental Safeguard Consultant at Strengthening the National Rural Transportation Program. His research interest are in the field of threatened and endangered species conservation. Dr. Bibhuti Ranjan Jha is a post-doc from Virginia Polytechnic Institute and State University, Blacksburg, VA, USA. PhD under collaboration between Kathmandu University, Dhulikhel, Nepal and University of Natural Resources and Life Sciences, Vienna. Academic-Research: ecology, wildlife, fish, river etc.

Author Contribution: SL developed the ideas, conducted the field and lab work, and prepared the manuscript. BRJ supervised the project.

Acknowledgements: The Department of National Park and Wildlife Conservation, Nepal is thanked for providing me with the opportunity to collect the scats. am grateful to Jhamak Bahadur Karki, Chief Warden, Chitwan National Park; Naresh Subedi, Robin Kodaria, Baburam Lamichhane and Sriram Ghimire of National Trust for Nature Conservation; Kumund Raj Kafle, Assistant Professor, Kathmandu University; John Seidensticker, Simthosian Conservation Biological Institute; Jai Ranganathan, Centre Associate, Santa Barbara, California; The Peerage of Science, Finland; Tirtha Raj Chowdhary, Sudip Raj Niroula, Mukesh Bhattarai, Sagar Dahal, Mahesh Thapa, Pratik Adhikary and Utsav Neupane for encouraging me to successfully complete the project.
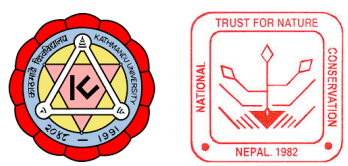


\section{INTRODUCTION}

Through centuries, the tiger Panthera tigris has been regarded as a predominant cultural icon and served as an effective umbrella species in conserving many forms of biodiversity in the Indian sub-continent (Karanth 2003). But, the expanding human population has put an increased pressure on tigers, its habitat, and prey as forests and grasslands are lost, degraded and fragmented leading the ungulate populations to decline precipitously, both in abundance and distribution (Sunquist et al. 1999). Further, human activities like hunting, logging, collection of non-timber forest products, animal husbandry, agricultural expansion and developmental projects have adversely influenced wildlife and their habitat (Karanth \& Madhusudan 2002) and there has been a strong negative effect on the population dynamics of the tiger (Reddy et al. 2004). Hence, conflicts with humans, prey depletion, poaching, and habitat loss and fragmentation remain the most apparent threats to tigers in the wild emphasizing the need to address these challenges (Ranganathan et al. 2008). Wikaramanayake et al. (2004) mentioned that the isolated population of large vertebrates in such refuges has a high probability of local extinction. Dinerstein et al. (2007) emphasized the required combination of financial commitments with action plan by the government and non-government sectors for tiger conservation in Nepal.

From 1846 the Tiger Panthera tigris habitat in Nepal has been blocked from development by royal policy that discouraged settlement and agriculture in the lowlands (terai) to maintain a malaria barrier to invading armies. However, in the 1950s, overpopulation in the middle hills and the massive malaria eradication program paved the way for a rapid increase in human population, primarily due to emigration (Smith et al. 1999). These changes resulted in the loss of the tiger's habitat. The National Park Act was framed in 1973 but habitat fragmentation had already divided the tiger into three separate populations namely, the Chitwan, Bardia, and Suklaphanta tiger populations. Very limited opportunities existed for genetic interactions between and among these isolated units (Shrestha 2004). Dinerstein et al. (2006) referred to them as conservation dependent species as they required protection, adequate prey base and adequate habitat area.

Knowledge of the food habits of the tiger in relation to its prey base is very essential for better management and understanding of the large cat ecology (Biswas \& Sankar 2002; Bagchi et al. 2003) because large carnivores play a major role in shaping prey communities (Karanth
\& Sunquist 1995), and food habits of the tiger enable us to recognize the plasticity in the predator's ability to choose from the available resources in different humanmodified ecological systems (Biswas \& Sankar 2002). The prey choice in tigers differ across its distributional range due to the diverse habitats it occupies (Bagchi et al. 2003).

Studies on the food habits of the tiger in Nepal has been one of the often addressed topics for biologists particularly since the 1970s (For example, McDougal 1976; Seidensticker 1976a; Bista 1979; Tamang 1979; Sunquist 1981; Smith et al. 1999; DNPWC/MoFSC/GoN 2009; Grey 2009; Wegge et al. 2009; Bhattarai 2011; Kapfer et al. 2011; Bhattarai \& Kindlmann 2012; Dahl 2012). The diet analysis study of tiger in Chitwan, Nepal appears discontinuous during the first decade starting 2000. The present research aims to contribute findings on the status of prey composition in tiger scat during 2010 in Chitwan. The study also infers that large as well as medium sized prey animals are important for the conservation of tiger in Chitwan National Park. In our study, we have focused on principal prey species namely, Sambar, Chital, Wildboar, Hog Deer, and Muntjac as designated by Seidensticker, (1976a).

\section{STUDY AREAS}

The Chitwan National Park (CNP) has been established from 1973 and covers an area of $932 \mathrm{~km}^{2}$ that comprise $12.1 \%$ terai (Paudel et al. 2008). The buffer zone covers $767 \mathrm{~km}^{2}$ (UNEP/WCMC 2008). The national park is located at the base of the outermost Himalaya, the Mahabharat Lekh, and on the south it is bounded by the low lying Churia and Siwaliks (Seidensticker 1976a). It lies $83^{\circ} 55^{\prime}-84^{\circ} 48^{\prime} \mathrm{E} \& 27^{0} 21^{\prime}-27^{\circ} 53^{\prime} \mathrm{N}$ (Gurung 2004) and varies in altitude from 150-815 m (UNEP/WCMC 2008).

The park consists of moist, semi-deciduous forests having an alluvial plain (Eisenberg 1976). The climax vegetation comprises Shorea robusta $70 \%$, grassslands $20 \%$ and riverine forest $7 \%$ (UNEP/WCMC 2008). The rest of the vegetation is Sal mixed with Pinus roxburghii (Gurung 2004). It is a protected place for the endangered rhinos and tigers and is home to more than 50 mammal species, over 525 birds and 55 amphibians and reptiles. The tiger population of CNP has increased to 125 adult tigers from 91 adult tiger in 2009 and 2011 (DNPWC 2011, DNPWC 2013) (Fig. 1). 


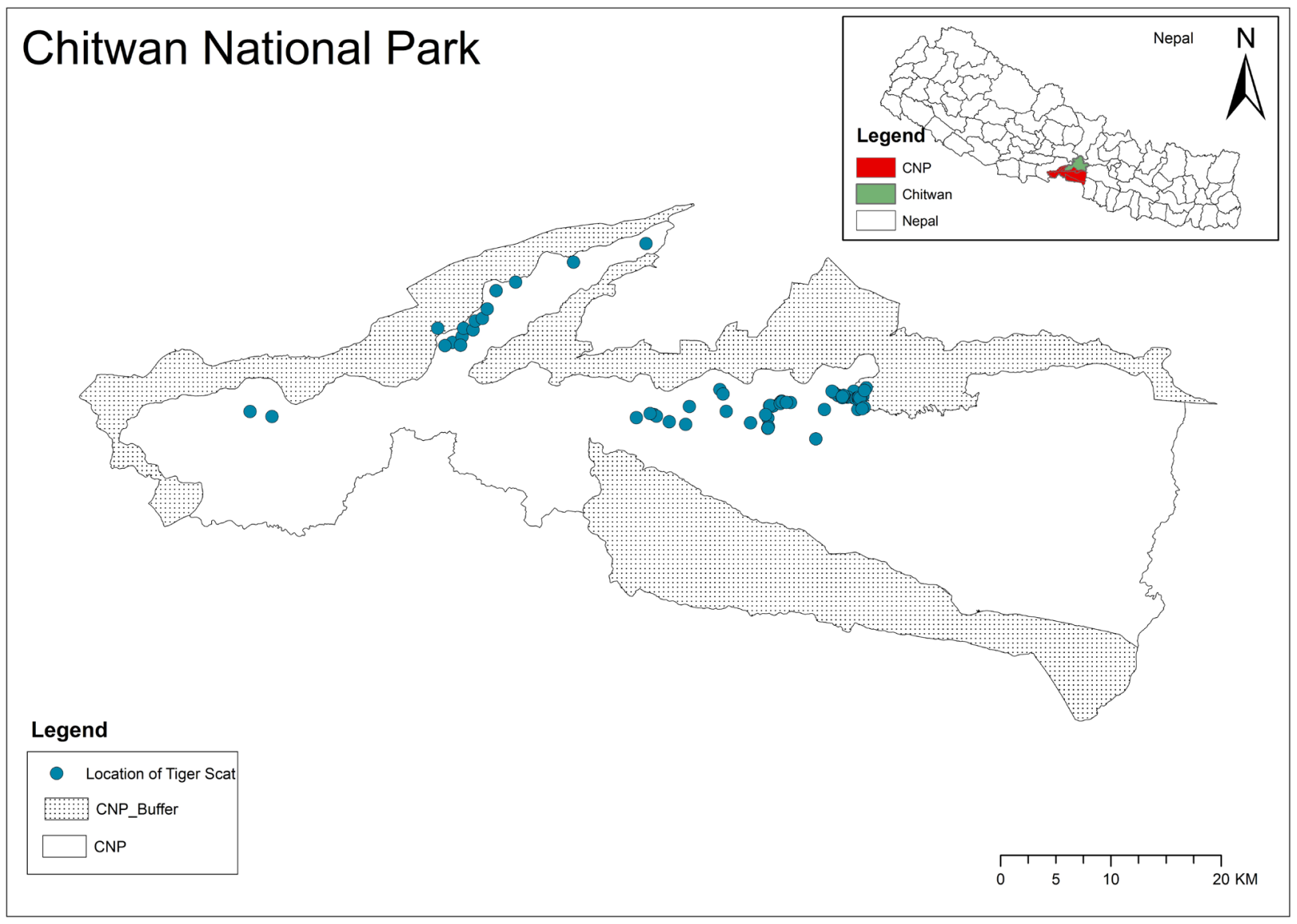

Figure 1. Chitwan National Park and its buffer zone (www.dnpwc.gov.np, 2011). The dots in the map represent GPS locations for scat samples collected during the study.

\section{METHODS}

\section{Collection and treatment of scats}

The scats of tigers were collected during the tiger survey of CNP from January 2010 to March 2010. The scats were collected opportunistically along the forest roads and trails as described in Adheria et al. (2007). Tiger scats were differentiated from other sympatric carnivores like leopard and Dhole if the stool diameter was $2.5 \mathrm{~cm}$ or greater, and the diameter of the entire deposition was greater than $15 \mathrm{~cm}$ as mentioned in Reddy et al. (2004). The size and shape of associated tracks and markings were also examined as described in Odden et al. (2010). Another guiding clue was that the tiger scats have lower degree of coiling and there is relatively a larger gap between two successive constrictions within a single piece of scat (Biswas \& Sankar 2002). Scats were omitted from documentation when the species was uncertain

Biswas \& Sankar (2002) have suggested that a minimum of 60 scat samples should be analysed to understand the pattern of prey use by tigers, and we have followed this recommendation. In the present study a total of 94 scats were encountered in 600 hours of survey out of which 89 were identified as the scat of tiger. After identification, a portion of the scat containing adequate amount of prey remains such as hair and other undigested body parts was stored in air tight plastic bags (Adheria et al. 2007). The collection date and location, including latitude and longitude from the global positioning system (GPS) was mentioned in each airtight plastic bag. A GIS map was prepared showing the distribution of collected scats. Sedeinsticker (1971) referred to the Sambar, Chital, Wild Boar, Hog Deer and Muntjac as the Principal prey species of Chitwan National Park. The hair samples of 12 other samples were discarded as these did not belong to any of the principal prey species. Therefore, 77 samples containing evidence of principal prey species of tiger were finally analysed and interpreted in the present study. 


\section{Scat Analysis}

The hair of prey species, which passed out undigested from the gut of predators, was the primary source of information for identifying the prey consumed (Adheria et al. 2007). The collected portion of the scat was placed in a plastic container filled with warm water containing detergent and carefully washed through a fine-meshed sieve to separate hairs from organic matter. The undigested remains such as bones, hooves and teeth were separated, and cleaned, and dried hair was stored in ziplock bags (Grey 2009). From each scat sample, 2030 hairs were randomly selected as mentioned in Odden et al. 2010. The selected hair samples for each scat sample were used for species identification following Mukherjee et al. (1994 a,b) and Kartz 2005. Here, the characteristics of hair like colour, width, medullary pattern, ratio of medulla width to hair width and the cuticular pattern of the hair were observed under the microscope and compared with the hair reference slides.

Estimation of relative biomass and number of prey consumed by tiger from scat analysis, using the correction factor

Frequencies of identifiable prey remains in scats do not give a representative picture of the consumed proportion of different prey species when the prey types vary in size to a considerable extent (Biswas \& Sankar 2002). It can be misleading because of the surface to volume ratio, i.e., smaller prey items have a relatively greater surface area to volume leading to the overestimation of smaller prey and underestimation of larger prey (Adheria et al. 2007). Thus, the frequency of occurrence of different prey items in scats misrepresents the relative number of prey species killed (Wegge et al. 2009). To correct the bias, the relative numbers of prey species killed by predators were analyzed using regression equations obtained by Ackerman et al. (1984) $(Y=1.98+0.035 X)$ in the results of fourteen feeding trials on captive cougars, where $Y$ is the biomass of prey consumed $(\mathrm{kg})$ to produce a single field collectable scat and $\mathrm{X}$ is the average body weight of the prey species $(\mathrm{kg})$. The expression has also been used by Bagchi et al. (2003) in their study from 109 tiger scats in Ranthambhore National Park in western India, and by Wang et al. (2010) to estimate the relative biomass and the numbers of prey consumed by carnivores in central Bhutan. The average weight of the principal prey species considered in our study were taken from the literature of Karanth \& Sunquist (1995). This average weight is used in other related studies like Biswas \& Sankar (2002), Bagchi et al. (2003), Grey (2009), and Wang et al. (2010). If the scat contained two prey items, each scat was counted as 0.5 prior to calculation of the frequency of occurrence (Karanth \& Sunquist 1995). Using the correction factor $Y$ and the average estimated weight $X$, the relative biomass $\mathrm{D}$ and the relative number of individuals killed $\mathrm{E}$ were estimated using the following equation: $D=(A \times Y)$ / $\Sigma(A \times Y) ; E=(D / X) / \Sigma(D / X)$

Prey species were classified into small $(<20 \mathrm{~kg})$, medium (20-50 kg) and large (>50 kg) based on their body mass to understand the pattern of the prey used by the tigers (Karanth \& Sunquist 1995; Biswas \& Sankar 2002; Adherai 2007; Grey 2009; Wang et al. 2010).

\section{Prey selection}

The observed proportion of prey species in the scats were compared with the expected proportions derived from their density to estimate and conclude whether tigers were showing selective predation, as discussed in Biswas et al. 2002 for their intensive study area in Pench National Park, India.

The expected proportion of scats from the kill of a particular species and the expected number of felid scats having a particular prey species under non selective predation were calculated by following the works of Karanth \& Sunquist (1995), Link and Karanth (1994), and Bagchi et al. (2003). In the multinomial relation $\pi i=d i \lambda i$ / $\Sigma i d i \lambda i$, prey species $i$ has a population density $d i$ and $\lambda i$ is the average number of felid-collectable scat produced by predator species from a single species $i(\lambda i=X i / Y i)$ and $\Sigma$ is the summation of each value of multiple of di $\lambda i$.

Next, the software SCATMAN (Hines \& Link 1994) was used to analyze prey selection by tigers. The frequency of occurrence of different prey items in the scats and the mean values and standard deviations of the prey density were specified in the software (Wegge et al. 2009). The variability in both the density estimates of each prey species ( $d i$ ) and the number of scats produced from a single species $(\lambda i)$ may increase the likelihood of the type I error (Link \& Karanth 1994), but the program also incorporated the effect of such variability and reduces the inflation of type I error to produce an unbiased probability value (Biswas et al. 2002). One thousand bootstrap iterations (Bagchi et al. 2003) were consequently performed and the coefficients of variation in scat production rates were set at $40 \%$ of the mean level (Karanth \& Sunquist 1995). The purpose of bootstrap was to understand the distribution of the statistics and the advantage is that we don't need to know the underlying distribution of our data, which we absolutely need to know if we are using an older method (eg: t-distirbution) (email conversation with Jai Ranganathan, 
Centre Associate, National Center for Ecological Analysis and Synthesis, Santa Barbara, California). The density of the principal prey species were taken from the report of the Government of Nepal, Ministry of Forests and Soil Conservation, Department of National Park and Wildlife Conservation (DNPWC/MoFSC/GoN 2009).

\section{RESULTS}

\section{Species composition of tiger diet}

The sample of 77 scats that was finally used for determining the composition of principal prey species of tiger contained 95 prey items. The randomly selected 20-30 hair samples contained either a single prey item $(23.38 \%)$ or two (76.62\%). Some of the scats also contained soil and grasses along with the prey items. Nine scats (11.68\%) contained the remains of bones and hooves. Tiger and Gaur hairs were not found in the samples analyzed. Chital and Sambar constituted the bulk (82.07\%) and Hog Deer, Wild Boar, and Muntjac constituted $17.93 \%$ in the tiger diet. The average weight of the Principal Prey species consumed by the Chitwan tiger was found to be $84 \mathrm{~kg}$ (Table 1 ).

\section{Prey selection}

The observed scat frequency for Sambar, Hog Deer, and Wild Boar were found greater than the estimated frequency represented by a positive sign (+). The reverse was true for the Chital and Muntjac represented by a negative sign (-). The adjusted $p$-value for the Hog Deer $(0.0042+)$ and Wild Boar $(0.0488+)$ showed preference as $p<0.05$, and Chital (0.0037-) was avoided. Similarly, Sambar (0.3017+) and Muntjac (0.5986-) were consumed more and less than their availability but consumption was statistically insignificant, i.e., the null hypothesis of no prey selectivity is true for them as $p>0.05$ (Table 2).

Table 1. Prey species composition in tiger scats $(n=77)$ and their percentage occurrence, frequency of occurrence and calculation of relative biomass and relative number of prey individuals killed by tigers, based on the scats collected in the Chitwan National Park during the tiger survey between January to March, 2010.

\begin{tabular}{|c|c|c|c|c|c|c|c|c|}
\hline & & & & A & $\mathbf{x}$ & $Y$ & D & E \\
\hline Prey & $\begin{array}{l}\text { No. of prey } \\
\text { items in total } \\
\text { number of } \\
\text { scat analyzed } \\
(n=77)\end{array}$ & $\begin{array}{c}\% \text { of } \\
\text { occurrence }\end{array}$ & $\begin{array}{c}\text { Scat } \\
\text { frequency } \\
\text { in total } \\
\text { number of } \\
\text { scat analyzed } \\
\text { (n=77) }\end{array}$ & $\begin{array}{l}\text { Frequency } \\
\text { of } \\
\text { occurrence } \\
\text { (\%) }\end{array}$ & $\begin{array}{c}\text { Estimated } \\
\text { weight } \\
\mathrm{X}(\mathrm{kg})\end{array}$ & $\begin{array}{c}\text { Correction } \\
\text { factor }(\mathrm{Y}) \\
\text { (kg of prey/ } \\
\text { scat) }\end{array}$ & $\begin{array}{c}\text { Relative } \\
\text { biomass } \\
\text { killed (\%) }\end{array}$ & $\begin{array}{c}\text { Relative } \\
\text { number of } \\
\text { individual } \\
\text { killed (\%) }\end{array}$ \\
\hline Chital (Axis axis) & 44 & 46.31 & 38 & 49.35 & 55 & 3.9 & 38.32 & 50.36 \\
\hline Sambar (Cervus unicolor) & 21 & 22.11 & 18 & 23.38 & 212 & 9.4 & 43.75 & 15.11 \\
\hline Hog Deer (Axis porcinus) & 15 & 15.79 & 11.5 & 14.93 & 40 & 3.38 & 10.04 & 17.98 \\
\hline Wild Boar (Sus scrofa) & 13 & 13.68 & 8 & 10.39 & 38 & 3.31 & 6.85 & 12.95 \\
\hline $\begin{array}{l}\text { Muntjac (Muntiacus } \\
\text { muntjac) }\end{array}$ & 2 & 2.10 & 1.5 & 1.95 & 20 & 2.68 & 1.04 & 3.60 \\
\hline Total & 95 & 100 & 77 & 100 & & & 100 & 100 \\
\hline
\end{tabular}

$D=(A \times Y) / \Sigma(A \times Y) ; E=(D / X) / \Sigma(D / X)$

Table 2. The observed and expected frequencies of prey items in the study of food habit of tiger from scat samples in Chitwan National Park, 2010. Bootstrap replications were set at 1000 and the variability in scat production rates was set at $40 \%$ of the mean level. Sign + and - indicates preference and avoidance respectively.

\begin{tabular}{|c|c|c|c|c|c|c|c|c|c|}
\hline Prey & $\begin{array}{l}\text { Observed } \\
\text { scat } \\
\text { frequency }\end{array}$ & $\begin{array}{c}\text { Scat } \\
\text { production } \\
(\lambda \mathrm{i}=\mathrm{X} / \mathrm{Y})\end{array}$ & $\begin{array}{l}\text { Density (individual/ } \\
\text { sq.km) (DNPWC/ } \\
\text { MoFSC//GoN, 2009) }\end{array}$ & $\begin{array}{l}\text { S.E Density } \\
\text { (individual/ } \\
\text { sq.km) }\end{array}$ & $\begin{array}{l}\text { Estimated } \\
\text { expected }\end{array}$ & $\begin{array}{c}\text { Chi- } \\
\text { square }\end{array}$ & $\begin{array}{l}\text { Unadjusted } \\
\text { P-value }\end{array}$ & $\begin{array}{l}\text { Adjusted } \\
\text { P-value }\end{array}$ & $\begin{array}{c}\text { Standard } \\
\text { error }\end{array}$ \\
\hline Chital & 38 & 14.10 & 43.9 & 10.6 & 51.57 & 10.8078 & 0.001 & $0.0037-$ & 0.0001 \\
\hline Sambar & 18 & 22.55 & 7.5 & 1.6 & 14.09 & 1.3283 & 0.249 & $0.3017+$ & 0.0020 \\
\hline Hog deer & 11.5 & 11.83 & 5.1 & 1.0 & 5.03 & 8.9202 & 0.003 & $0.0042+$ & 0.0001 \\
\hline Wild boar & 8 & 11.48 & 4.2 & 0.9 & 4.02 & 4.1671 & 0.041 & $0.0488+$ & 0.0003 \\
\hline Muntjac & 1.5 & 7.46 & 3.7 & 0.6 & 2.30 & 0.2865 & 0.592 & $0.5986-$ & 0.0007 \\
\hline
\end{tabular}

$\mathrm{X}=$ average body weight of the prey species $(\mathrm{k} . \mathrm{g}) ; \mathrm{Y}=$ biomass of prey consumed $(\mathrm{k} . \mathrm{g})$ to produce a single field collectable scat. 


\section{DISCUSSION}

Biswas \& Sankar (2002) and Bagchi (2003) mentioned that the high availability of larger prey in the study area would be expected to influence prey selection by tigers as they are usually known to have a predilection for larger prey. In contrast, the present study showed that the tiger preferred more of medium sized prey species. Karanth \& Sunquist (1995) and Biswas \& Sankar (2002) added that the predilection of tiger for medium size prey species may disturb the park's carnivore community such as other carnivores (e.g., Leopard) that were successful. Hence, this predilection to medium size prey species may bring disturbances in the park's community of Chitwan National Park.

Kapfer et al. 2011 mentioned that the composition of tiger diet was unrelated to the prey density and supported the view that tigers actively select the larger prey just by heavy reliance on prey size. The largest prey is Sambar in their data. We think that the factor that determines the selection of prey species is not only its biomass. There are other factors involved. If it was only the larger size, then with time and active selection, it becomes harder and harder for tiger to capture the larger prey species, and at a point the prey is not profitable to the predator in terms of energy to handling time, i.e., the predator would require more and more time searching for larger prey species. Hence, the predator must shift to profitable species. The profitable species may be of medium size and higher density that make them easier to be captured. In our study the positive selection of Axis axis appears profitable to the predator in terms of its biomass, density, and vulnerability to predation. There are other factors like solitary nature, nocturnal habitat, age and health of predator and prey etc. that determine predation profitability, but density of the prey is regarded as one of the crucial factors for predator to determine its prey, as obvious in foraging theory. In our analysis the contribution of Sambar was the highest in terms of biomass (similar to Kapfer et al. 2011) but when prey selectivity was calculated for Sambar, the null hypothesis of no prey selectivity is true for them as $p>>0.05$ whereas medium size species were preferred. Hence, it is necessary to incorporate the prey selectivity which is not found in Kapfer et al. (2011). Since the authors in Kaupfer et al. (2011) are experts, we only present our views and suggestions are welcome. Similarly, the SCATMAN Software developed by experts lays emphasis on 'density' as the software requires the density of prey to calculate its selectivity, i.e., this software is used to test the hypothesis of prey selectivity based on random samples of predator scat (Table 3 ).

Biswas \& Sankar (2002) and Bagchi et al. (2003) mentioned that the multiple prey items are rare in scats of large predators such as tiger. This study showed a similar result. None of the randomly selected hair samples contained more than two prey items. Further, the 'per cent occurrence' is considered a more appropriate method of quantifying the diet of carnivores than 'frequency of occurrence' as it accounts for more than one of a given item being found in a scat (Grey 2009). In our study both the approaches showed similar results.

In the present study Chital constituted relatively the most killed (50.36\%) species. This may be because they forage around moist streams and small grass clearings, surrounded by forest on three sides which make them vulnerable to predation by tigers since it uses terrain, cover and habitat features for stalking its prey (Karanth \& Sunquist 2000). Similarly, the nocturnal habit and solitary nature of Sambar (Biswas \& Sankar 2002; Bagchi et al. 2003; Grey 2009) may have made them vulnerable to predation by Tiger. But, Sambar contributed the largest bulk (43.75\%) which shows its importance in

Table 3. Comparison of frequency of occurrence, relative no. of individuals killed, relative biomass killed and density of ungulates of Chitwan National Park at different time frames.

\begin{tabular}{|c|c|c|c|c|c|c|c|c|c|}
\hline \multirow[t]{2}{*}{ Species } & \multicolumn{3}{|c|}{ Frequency of occurrence } & \multicolumn{2}{|c|}{$\begin{array}{l}\text { Relative no. of individual } \\
\text { killed }\end{array}$} & \multicolumn{2}{|c|}{$\begin{array}{c}\text { Relative biomass } \\
\text { consumed }\end{array}$} & \multicolumn{2}{|c|}{ Density of ungulates (Individuals $/ \mathrm{km}^{2}$ ) } \\
\hline & $\begin{array}{l}\text { McDougal } \\
1977\end{array}$ & $\begin{array}{c}\text { Sunquist } \\
1981\end{array}$ & $\begin{array}{c}\text { Present } \\
\text { Study } \\
2010 \\
\end{array}$ & $\begin{array}{c}\text { McDougal } \\
1977\end{array}$ & $\begin{array}{l}\text { Present } \\
\text { Study } \\
2010 \\
\end{array}$ & $\begin{array}{c}\text { McDougal } \\
1977\end{array}$ & $\begin{array}{l}\text { Present } \\
\text { Study } \\
2010 \\
\end{array}$ & $\begin{array}{c}\text { Seidensticker } \\
1976 a\end{array}$ & $\begin{array}{l}\text { Present Ungulates } \\
\text { Density (DNPWC/ } \\
\text { MoFSC/GoN, 2009) }\end{array}$ \\
\hline Chital & $61.8^{\mathrm{a}}$ & 33.3 & 49.35 & 27.8 & 50.36 & 24.73 & 38.32 & 17.3 & 43.9 \\
\hline Sambar & 20 & 29.3 & 23.38 & 15.3 & 15.11 & 54.72 & 43.75 & 3.9 & 7.5 \\
\hline Hog deer & & 15.4 & 14.93 & 13.5 & 17.98 & 11.39 & 10.04 & 35 & 5.1 \\
\hline Wild boar & 3.6 & 10.6 & 10.39 & 10.8 & 12.95 & 6.94 & 6.85 & 5.8 & 4.2 \\
\hline Muntjac & & 4.1 & 1.95 & 6.4 & 3.60 & 2.22 & 1.04 & 6.7 & 3.7 \\
\hline
\end{tabular}

$\mathrm{a}=$ frequency of occurrence of sum of Chital, Hog Deer and Muntjac. 
maintaining the tiger population in CNP. The solitary nature and groups containing two or three individuals of Hog Deer and Wild Boar may lead to increased tiger predation (Biswas \& Sankar 2002). A study conducted in one of the sites in the Sikhote-Alin mountain area of Russia showed that a high overlap of habitat use between tigers and wild boar may have favoured a high level of tiger predation on Wild Boar (Miquelle et al. 1991). In this context, there is the need to study the overlap of habitat use by Wild Boar and Tiger in the Indian sub-continent. In case of the Muntjac, the observed predation (1.5) was less than the expected (2.3) and also the selection of Muntjac (0.5986-) was statistically insignificant ( $p>0.05)$. This may be due to its small size $(20 \mathrm{~kg})$ and diurnal activity. The shy nature and low densities across its present distributional ranges may be another reason that reduced chances of predation of Muntjac by tiger as mentioned in Schaller 1967.

We couldn't imagine the world without the tiger (Dinerstein et al. 2006) and saving the tiger means not only saving the species but it is the symbol that reflects the health of the forest (Banks et al. 2003). It is well known that the tiger needs an undisturbed large habitat with abundant large wild ungulate prey. Hence it is impossible to save the species in small forest fragments (Karanth \& Stith 1999). The continuous decrease in these features of the habitat due to human activities is placing a strong negative effect on its density (Panquet \& Darimont 2010). In Asia, as in the rest of the world, many of the protected areas are too small to support a viable population of large mammals (Wikramanayake et al. 2004). It is very necessary to form linkages to join these areas and this objective could be achieved by international links/actions and regional cooperation through bodies like ASEAN and SAARC and with regular monitoring of the ungulate densities (Dinerstein et al. 2007). Karanth \& Stith (1999) suggested that the low density or absence of tiger in many regions may be largely due to the decrease in ungulate densities. The study done by Biswas \& Sankar (2002) and Reddy et al. (2004) showed that the tiger may not take livestock if there is abundant wild ungulates and so could reduce the human and tiger conflict. Here, the larger size species constituted the most selected by biomass and the number of individuals killed and the medium sized were preferred for selection. Hence, the present study showed that the large as well as medium sized ungulates are needed in the habitat to conserve tiger population in Chitwan National Park. This can be done by applying effective strategies to deploy armed patrols to deter hunters, eliminate snares, traps, pitfalls, baits and other such devices (Karanth \& Stith 1999). In addition, other very effective strategies that could contribute to increase the tiger population (Conversation with the WWF Staff 2012 Kathmandu Nepal) are alternate income generating works for people and their education on the importance of the wildlife and forest.

\section{REFERENCES}

Ackerman, B.B., F.G. Lindzey \& T.P. Hemker (1984). Cougar food habits in southern Utah. Journal of Wildlife Management 48(1): 147-155.

Adheria, A.P., K.U. Karanth \& N.S. Kumar (2007). Diet and prey profiles of three sympatric large carnivores in the Bandipur Tiger Reserve, India. Journal of Zoology 273(2): 169-175.

Bagchi, S., S.P. Goyal, \& K. Sankar (2003). Prey abundance and prey selection by Tiger (Panthera tigris) in semi-arid, dry deciduous forest in western India. Journal of Zoology 260(3): 285-290.

Banks, D., N. Mole \& P. Shah (eds.) (2003). Undermined: Destruction of Tiger Habitat in India. Environmental Investigation Agency, London / Washington DC, 18pp.

Bhattarai, B.P. (2011). Challenges of Bengal Tiger (Panthera tigris tigris) conservation in the tropics: lessons learned from the Chitwan National Park of Nepal. PhD Thesis, in English. Faculty of Science, University of South Bohemia, České Budějovice, Czech Republic, 51pp+Appendices 255pp.

Bhattarai, B.P. \& P. Kindlmann (2012). Habitat heterogeneity as the key determinant of the abundance and habitat preference of prey species of tiger in the Chitwan National Park, Nepal. Acta Theriologica http://dx.doi.org/10.1007/s13364-011-0047-8

Bista, R.B. (1979). Status of Tiger in Nepal, pp. 17-20. In: International Symposium on Tiger, India, February 22-24, 1979. Papers, Proceedings and Resolutions. Project Tiger, Government of India, Department of Environment, New Delhi 1979, ix+417pp.

Biswas, S. \& K. Sankar (2002). Prey abundance and food habitat of Tigers (Panthera tigris tigris) in Pench National Park, Madhya Pradesh, India. Journal of Zoology 256(3): 411-420.

Dahl, S. (2012). Contribution of small mammals to the diet of tiger: a case study of Chitwan National Park. A thesis submitted in partial fulfillment of the requirements for the Degree of Master of Science in Zoology, Central Department of Zoology - Ecology Program Institute of Science and Technology, Tribhuvan University, Kathmandu, Nepal, xiv+77pp.

Dinerstein, E., C. Loucks, A. Heydlauff, E. Wikramanayake, G. Bryja, J. Forrest, J. Ginsberg, S. Klenzendorf, P. Leimgruber, T. O’Brien, E. Sanderson, J. Seidensticker \& M. Songer (2006). Setting Priorities for the Conservation and Recovery of Wild Tigers: 2005-2015. A User's Guide. 1-50. Washington, D.C. - New York, WWF, WCS, Smithsonian, and NFWF-STF.

Dinerstein, E., C. Loucks, E. Wikramanayake, J. Ginsberg, E. Sanderso, J. Seidensticker, J. Forrest, G. Bryja, A. Heydlauff, S. Klenzendorf, P. Leimgruber, J. Mills, T. O'Brien, M. Shrestha, R. Simons \& M. Songer (2007). The fate of Wild Tigers. Bioscience 57(6): 508-514.

DNPWC (2011). <http://www.dnpwc.gov.np/protected-areas/ national-parks/8-chitwan-national-park.html>. Downloaded on 4 January 2011.

DNPWC/MoFSC/GoN (2009). Tiger and their prey base abundance in Terai Arc Landscape. Department of National Park and Wildlife Conservation, Ministry of Forests and Soil Conservation, Government of Nepal.

Eisenberg, J.F. (1976). Ungulates in southern Asia. A consideration of biomass estimates for selected habitats. Biological Conservation 10(4): 293-308.

Grey, J. (2009). Prey selection by Tiger (Panthera tigris tigris) in the Karnali Floodplain of Bardia National Park, Nepal. MSc Thesis. Imperial College, London. 
Gurung, M.K. (2004). Human Dimensions in One-horned Rhinoceros Conservation in Royal Chitwan National Park, Nepal. MSc Thesis. University of Boku, Vienna, Austria.

Hines, J.E. \& W.A. Link (1994). Scatman Software. <http://search.nasa. gov/search/search.jsp?nasalnclude=Scatman $>$. Downloaded on 2 January 2011.

Kapfer, P., H.M. Streby, B. Gurung, A. Simcharoen, C.C. McDougal \& J.L.D. Smith (2011). Fine-scale spatio-temporal variation in Tiger Panthera tigris diet: effect of study duration and extent on estimates of tiger diet in Chitwan National Park,Nepal. Wildlife. Biology 17(3): 277-285.

Karanth, K.U \& M.E. Sunquist (1995). Prey Selection by Tiger, Leopard and Dhole in Tropical Forests. Journal of Animal Ecology 64(4): 439450.

Karanth, K.U. \& B.M. Stith (1999). Prey depletion as a critical determinant of tiger population viability, pp. 100-113. In: Seidensticker, J., S. Christie \& P. Jackson (eds.). Riding the Tiger: Tiger Conservation in Human-dominated Landscapes. Cambridge University Press, Cambridge, UK.

Karanth, K.U. \& M.E. Sunquist (2000). Behavioural correlates of predation by Tiger (Panthera tigris), Leopard (Panthera pardus) and Dhole (Cuon alpinus) in Nagahole, India. Journal of Zoology 250(2): 255-265.

Karanth, K.U. \& M.D. Madhusudan(2002). Mitigating human - wildlife conflicts in southern Asia, pp. 250-264. In: Terburgh, J., C.V. Schaik, L. Davenport \& M. Rao (eds.). Making Parks Work, Strategies for Preserving Tropical Nature. Island Press, Washinton, USA.

Karanth, K.U. (2003). Tiger Ecology and Conservation in Indian subcontinent. Journal of the Bombay Natural History Society $100(2 \& 3)$ : 169-189.

Karanth, K.U., J.D. Nicholas, N.S. Kumar, W.A. Link \& J.E. Hines (2004). Tigers and their prey: predicting carnivores densities from prey abundance. PNAS 101(14): 4854-4858.

Katz, D.A. (2005). Hair Analysis. www.chemist.com/HAIR\%20ANALYSIS Pdf (accessed 3 Dec, 2010).

Link, W.A. \& K.U. Karanth (1994). Correcting for overdispersion in tests of prey selectivity. Ecology 75(8): 2456-2459.

McDougal, C. (1977). The Face of The Tiger. Rivington Books, London,UK.

Mukherjee, S., S.P. Goyal \& R. Chellam (1994a). Refined techniques for the analysis of Asiatic Lion Panthera leo persica scats. Acto Theologica 39(3): 425-430.

Mukherjee, S., S.P. Goyal \& R. Chellam (1994b). Standardisation of scat analysis techniques for Leopards (Panthera pardus) in Gir National Park, Western India. Mammalia 58(1): 139-143.

Odden, M., P. Wegge \& T. Fredriksen (2010). Do tigers displace leopards? If so, why? Ecological Research 25(4): 875-881.

Paudel, K.C., B.J. Karki \& R.S. Bhatta (2008). Trans-boundary conservation initiatives in Nepal, pp 29-33. In: Bajracharya, S.B. \& N. Dahal (eds.). Shifting Paradigms in Protected Area Management. National Trust for Nature Conservation, Kathmandu, Nepal.

Paquet, P.C. \& C.T. Darimont (2010). Wildlife Conservation and Animal Welfare: two sides of the same coin? Animal Welfare 19(2): 177190.

Ranganathan, J., K.M.A. Chan. \& J.L.D Smith (2008). Where can tiger persist in the future? A land scape-scale, density-based population model for the Indian sub-continent. Biological Conservation 141(1) 67-77.

Reddy, H.S., C. Srinivasulu \& K.T. Rao (2004). Prey selection by Indian Tiger (Panthera tigris tigris) in Nagarjunasagar Srisailam Tiger Reserve, India. Mammalian Biology 69(6): 384-39.

Schaller, G.B. (1967). The Deer and The Tiger. University of Chicago Press, Chicago, London, 370pp.

Seidensticker, J. \& C. McDougal (1993): Tiger predatory behaviour, ecology and conservation. Symp. Zool. Soc. London, 65: 105-125.

Seidensticker, J. (1976a). On the ecological separation between tigers and leopards. Biotropica 8(4): 225-234.

Seidensticker, J. (1976b). Ungulate populations in Chitwan Valley, Nepal. Biological Conservation 11/1976: 10(3): 183-210.
Shrestha M.K. (2004). Relative Ungulate Abundance in a Fragmented Landscape: Implication for Tiger conservation. PhD Thesis. University of Minnesota, USA.

Smith, J.L.D., C. Mc Dougal, S.C. Ahearn, A. Joshi \& K. Conforti (1999). Metapopulation structure of tigers in Nepal, pp 176-192. In: Seidensticker, J., S. Christie \& P. Jackson (eds.). Riding the Tiger: Tiger Conservation in Human Dominated Landscapes. Cambridge University Press, Cambridge, UK.

Stoen, O.G. \& P. Wegge (1996). Prey selection and removal by Tiger (Panthera tigris) during the dry season in lowland Nepal. Mammalia 1996: 363-373.

Sunquist, M.E. (1981). The social organization of Tigers (Panthera tigris) in Royal Chitwan National Park. Smithsonian Contributions to Zoology 336: 1-98.

Sunquist, M.E., K.U. Karanth \& F.C. Sunquist (1999). Ecology, behavior and resilience of the tiger and its conservation needs, pp. 5-18. In: Seidensticker, J., S. Christie \& P. Jackson (eds.). Riding the Tiger: Tiger Conservation in Human-dominated Landscapes. Cambridge University Press, Cambridge, UK.

Tamang, K.M. (1979). Population characteristics of the Tiger and its prey, pp. 236-244. In: International Symposium on Tiger, India, February 22-24, 1979. Papers, Proceedings and Resolutions. Project Tiger, Government of India, Department of Environment, New Delhi 1979, ix+417pages.

UNEP/ WCMC (2008). Royal Chitwan National Park, Nepal. United Nations Environment Programme, World Conservation Monitoring Centre. <http://www.unep-wcmc.org/medialibrary/2011/06/13/ e26c7182/Royal\%20 Chitwan.pdf> . Downloaded on 4 January 2011.

Wang, S.W. \& D.W. Macdonald (2010). Feeding habits and niche partitioning in a predator guild composed of tigers, leopards and dholes in a temperate ecosystem in Central Bhutan. Journal of Zoology [April 2009] 277(4): 275-283

Wegge, P., M. Odden, C.P. Pokharel \& T. Storass (2009). PredatorPrey relationships and responses of ungulates and their predators to the establishment of protected areas: A case study of tigers, leopards and their prey in Bardia National Park, Nepal. Biological Conservation 142(1): 189-202.

Wikramanayake, E., M. McKnight, E. Dinerstein, A. Joshi, B. Gurung \& D. Smith (2004). Designing a conservation landscape for tigers in human-dominated environments. Conservation Biology 18(3): 839-844

Nepali Abstract: सारांश: चितवन राष्ट्रिय निकुज्ज, नेपालको मुख्य शिकार प्रजातिका अवशे ष भेटिएका ७७ वटा पाटे बाघका दिसाबाट बाघको शिकार छनौटको अध्ययन गरियो। वि स २०६६ पौष देखी फाल्गण महिना सम्म बाघका दिसाहरु सङकलन तथा विष्लेषण गरियो। चितवन राष्ट्रिय निक्ज्जमा पाइने शाकाहारी जनावरहरुका सम्बन्धमा नेपाल सरकारको प्रतिवेदनमा (वि.स.२०६४) मख्य शिकार प्रजातिको घनत्वको मुलभत तथ्याङ्क उपलब्ध रहेको छ। शिकार छनोट बभभ्ने बिषयमा भेटिएको शिकारका मुख्य प्रजातिका अनुपातलाई घनत्व आङ्कलनबाट प्राप्त आशातित अनुपातसंग तुलना गरियो। दिसामा पाइएको साम्बर,लगुना, र वंदेलका अवशेषका पुनरावत्ति अनुमानित पुनर ववृत्ति भन्दा बढ़ी पाइयो तर चित्तल र रतुवाका सन्दर्भमा भने यसको विपरित पाइयो। मारिएका मुख्य शिकार प्रजातिको औसत तौल ५ मुख्य अंश साम्बर र चित्तल (५२.०७ \%) रहेका र बाँकी (१७९३ \%) लगुना, वंदेलका र रतुवा रहेको भेटियो, त्यसमा पनि शिकार संरचना हेर्दा अत्याधिक अंश साम्वरले ओगटेको (४३.७५ \%) र तुलनात्मक रुपमा वढी मारिनेमा चित्तल (५०.३६ \%) रहेको भेटियो । यस अध्ययनले चितवन राष्ट्रिय निकुज्जमा रहेका पाटे बाघहरुको शिकार संरचनाको अवस्था वि.स. २०६६ बभ्भन्न योगदान गई र बाघका संरक्षणमा ठुला तथा मध्यम आकारका शिकारहरुको महत्व चितवन राष्ट्रिय निकुज्जमा रहेको देखाउन सकिन्छ।

पाटे बाघ, मुख्य शिकार प्रजाति, शिकार छनौट, बाघका दिसा विष्लेषण ।
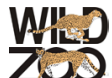